\title{
CFRP 板が接着された鋼板に生じる熱応力の低減工法の開発
}

Development of Reduction Technique of Thermal Stress Induced in Steel Plate Bonded by CFRP Plates

\author{
石川毎攵之*・服部篤史**・河野层隆***・長尾隆史 $・$ 小林 朗 \\ Toshiyuki ISHIKAWA, Atsushi HATTORI, Hirotaka KAWANO, Takashi NAGAO and Akira KOBAYASHI \\ *博士(工) 京都大学助教, 工学研究科都市社会工学専攻（二615-8540 京都府京都市西京区京都大学桂） \\ **博士(工) 京都大学准教授, 工学研究科都市社会工学専攻（广615-8540 京都府京都市西京区京都大学桂) \\ ***博士(工) 京都大学教授, 工学研究科都市社会工学専攻（干615-8540 京都府京都市西京区京都大学桂） \\ †修士(工) 日本軽金属(株)，グループ技術センター（†421-3291 静岡県静岡市清水区蒲原 1-34-1） \\ サ工修，新日鉄マテリアルズ株，日鉄コンポジット社 社会資本材料事業部
}

（干103-0024 東京都中央区日本橋小舟町 3-8）

\begin{abstract}
In CFRP bonded onto steel plate, thermal stress is induced in steel plate by temperature change, due to difference in coefficients of thermal expansion between steel and CFRP. In this study, reduction technique of the thermal stress in steel plate, which is additional bonding of aluminum alloy plates, is proposed. Namely, the coefficient of thermal expansion of composite plate consisted of CFRP and aluminum plates is designed as that of steel. In this research, to verify the effectiveness of developed method, heat tests of CFRP and aluminum plates bonded onto steel plate were carried out. As a result of the tests, infinitesimal thermal stresses in steel plate with CFRP and aluminum plates were measured while large thermal stresses were measured in conventional CFRP bonded onto steel plate. Additionally, to confirm the test results, numerical analysis was also carried out.
\end{abstract}

Key Words: CFRP plate, aluminum alloy plate, thermal expansion, thermal stress

\section{1. はじめに}

鋼部材の補修・補強工法として，炭素䋊維強化樹脂成形 板(以下，CFRP 板と呼ぶ)を接着する方法が国内外で行わ

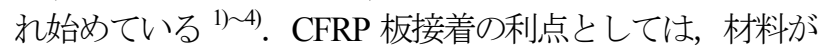
軽量であるので施工時のハンドリングが容易であること, 接着するだけで補修・補強できるので, 鋼部材にボルト孔 を設けるなど特別な加工が必要ないことが挙げられる.し かし，CFRP 板の線膨長係数がほぼ $0 \mu$ 「Cであるため，温 度変化を受けると CFRP 板が接着された鋼部材には内部 応力(以下, 熱忘力と呼ぶ)が生じる ${ }^{5), 6) . こ れ ま て ゙ に, ~ C F R P ~}$ 板接着による鋼構造物の補修・補強において, 熱忘力を考

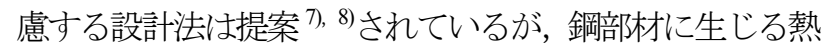
応力自体を下げる研究は行われていない.

本研究では，CFRP板が上下面に対称に接着された鋼板 を対象に, 温度変化によって鋼板に生じる熱応力を低減さ せる方法として, 線膨長係数が鋼の約 2 倍のアルミニウム 合金板 (以下 $\mathrm{AL}$ 板と呼ぶ) を CFRP 板と共に鋼板に接着 する方法を提案する. そして, 鋼板の上下面にCFRP 板と AL 板が接着された試験体に温度変化を与えて, 開発した 工法による鋼板の熱応力の低減効果を明らかにする.さら
に，数值解析を行い，本工法の有効性を明らかにする.

\section{2. $\mathrm{AL}$ 板の必要伸ひ凬性の設計}

一般に，炭素䋊維の繊維含有率を変化させることにより， CFRP 板の線膨張係数を設定することができる. しかし， マトリクス樹脂のヤング率が炭素繊維と比べて非常に小 さいので, CFRP 板の線膨張係数を鋼と同程度にすると, 繊維含有率が小さくなり, 力学的性質がそしくなる. そこ で, 鋼板に生じる熱応力を低減させる方法として, CFRP 板に加え, ヤング率 $70 \mathrm{GPa}$, 線膨張係数 $23 \mu$ 个Cの AL 板 を鋼板に接着する工法を提案する.つまり, CFRP 板と $\mathrm{AL}$ 板が接着され一体となった合成板の線膨張係数を，鋼 板の線膨張係数に近づることによって，CFRP 板と AL 板が接着された鋼板に生じる熱応力を小さくする.

CFRP 板と AL 板が接着され, 一体となった 合成板の線 膨張係数 $\alpha_{v}$ は, 各 CFRP 板と各 $\mathrm{AL}$ 板の熱伸縮による内 力のつり合いから次式で与えられる.

$$
\alpha_{v}=\frac{\alpha_{f} E_{f} A_{f}+\alpha_{a} E_{a} A_{a}}{E_{f} A_{f}+E_{a} A_{a}}
$$




$$
\begin{aligned}
& \text { ここに, } \\
& E_{f}, E_{a} \text { : それぞれ，CFRP板とAL板のヤング率, } \\
& A_{f}, A_{a}: \text { それぞれ，CFRP板とAL板の断面積, } \\
& \alpha_{f}, \alpha_{a}: \text { それぞれ, CFRP板とAL板の線膨張係数 } \\
& \text { ( } \mu \rho \mathrm{C}) \text {. }
\end{aligned}
$$

式(1)の $\alpha_{v}$ を鋼の線膨張係数 $\alpha_{s}$ に置換し, CFRP 板に対 寸る $\mathrm{AL}$ 板の伸ひ風性比 $E_{a} A_{a} /\left(E_{f} A_{f}\right)$ に対して解いて 次式を得る.

$$
\frac{E_{a} A_{a}}{E_{f} A_{f}}=\frac{\alpha_{s}-\alpha_{f}}{\alpha_{a}-\alpha_{s}}
$$

この式に，鋼，CFRP板およびアルミニウム合金の線膨 張係数を代入して，CFRP 板と AL 板の合成板の線膨張係 数を，鋼板のそれと等しくする CFRP 板の伸ひ㸃性に対寸 る $\mathrm{AL}$ 板の伸ひ凮性が設計できる。

\section{3. 試験条件}

\section{1 試験体}

図一 1 に示寸, 厚さ $4.5 \mathrm{~mm}$, 幅 $25 \mathrm{~mm}$ の鋼板の上下面に, ヤング率 $140 \mathrm{GPa}$, 厚さ $1 \mathrm{~mm}$, 幅 $25 \mathrm{~mm}$ の CFRP 板 2 枚を それぞれ接着した場合(従来工法)を対象として, 開発工法 による熱灾力の低減効果を明らかにする. 鋼板の補修・補 強効果を一定にするために, CFRP 板と AL 板の和の伸び 剛性を，図一1のCFRP 板の伸ひ凮性と同じになるように 設計する.

接着する $\mathrm{AL}$ 板の伸ひ㧫性を設計するために, 鋼板の線 胿長係数 $\alpha_{s}$, CFRP 板の線膨長係数 $\alpha_{f}$ および $\mathrm{AL}$ 板の線 膨張係数 $\alpha_{a}$ をそれぞれ， $\alpha_{s}=12 \mu \rho \mathrm{C}, \alpha_{f}=1 \mu \rho \mathrm{Cおよ}$

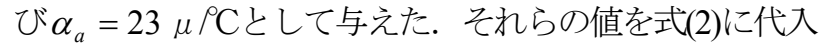
して, $E_{a} A_{a} /\left(E_{f} A_{f}\right)=1$ を得る. したがって, $\mathrm{AL}$ 板の伸 ひ岡性を CFRP 板のそれと等しくすることにより, CFRP 板と $\mathrm{AL}$ 板の合成板の線膨張係数を, 鋼板のそれと等しく することができる. すなわち, 図一1に対して, 鋼板の片 面に接着された2枚のCFRP板のうち, 1 枚のCFRP板を, それと同じ伸ひ凮性の AL 板に置換する. AL 板のヤング 率が 70GPa(CFRP 板の $1 / 2$ 倍)であるので, 熱応力を低減さ せる AL 板の断面は CFRP 板の 2 倍になる. このように設 計した, CFRP 板と AL 板が接着された鋼板を図-2〜4に 示寸. 図-4の試験体 $\mathrm{ACA}$ には, 各 $1 \mathrm{~mm} の \mathrm{AL}$ 板の間に CFRP 板が接着された 3 層の積層板としている. 図-2〜4 の試験体に加え, 図一 1 で示した CFRP 板が 2 枚接着され た試験体 CC および，鋼板の両面に $2 \mathrm{~mm} の \mathrm{AL}$ 板が各 2 枚接着された試験体 AA の温度変化試験も行った.

CFRP 板接着による補修・補強では，接着剂を介して鋼 板と CFRP 板あるいはAL 板の相互の力が伝達される.し たがって，鋼板，CFRP 板および $\mathrm{AL}$ 板間の力の伝達が十 分になされるように接着長さを設計する必要があるが, 本 研究では, 試験に用いた乾燥炉の大きさから CFRP 板およ び AL 板の長さを $100 \mathrm{~mm}$ (鋼板の長さ $160 \mathrm{~mm}$ ) とした. 後 に示寸, 計測した試験体の寸法および材料定数を, 文献

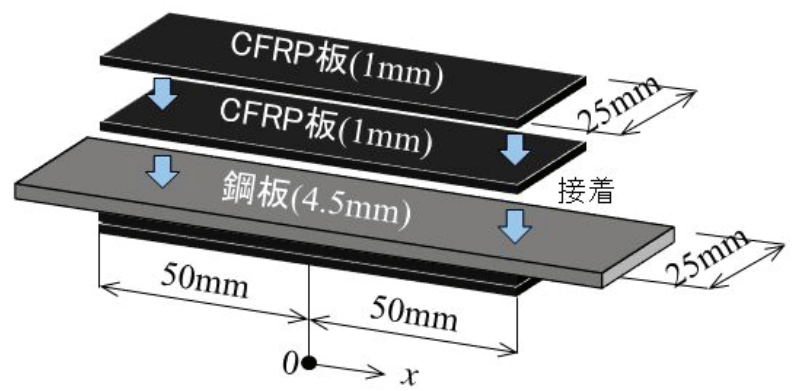

図-1 対象とするCFRP板接着鋼板(試験体CC)

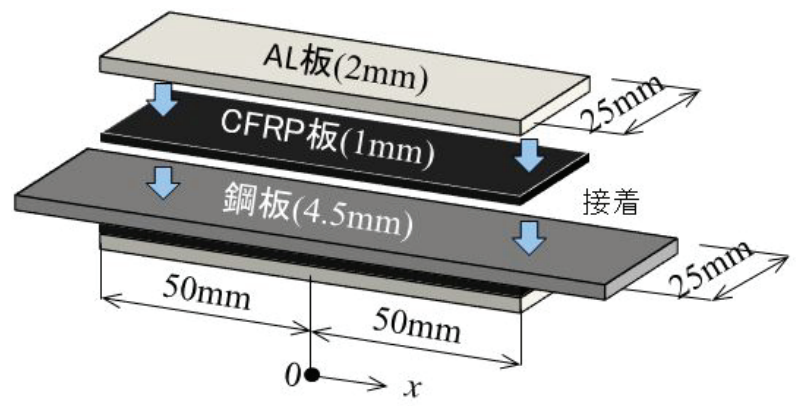

図-2 試験体CA

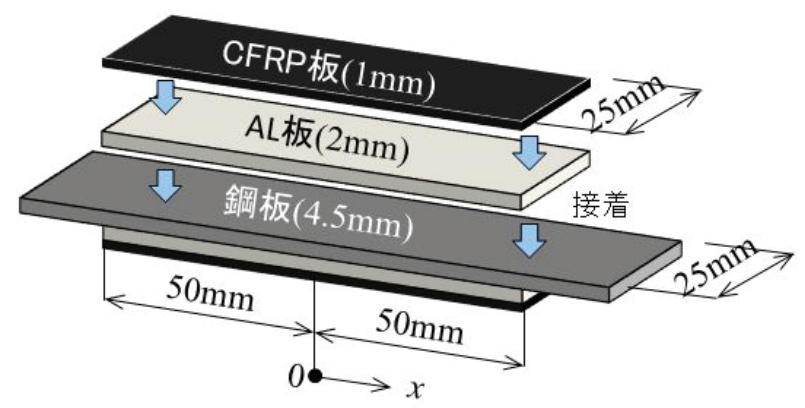

図-3 試験体AC

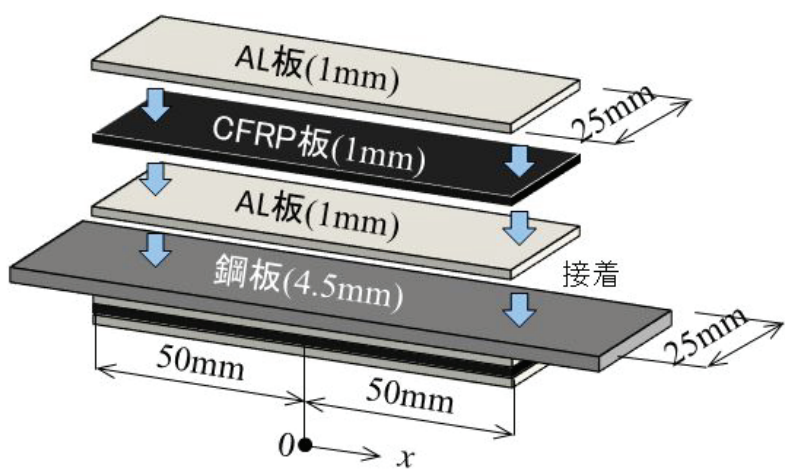

図-4 試験体ACA

9)で提案されている複数枚のCFRP板が接着された場合に 対する CFRP 板の必要接着長さの算定式に代入して, $\mathrm{CFRP}$ 板あるいは $\mathrm{AL}$ 板の必要接着長さを算出すると, 試 験体 $\mathrm{CC}, \mathrm{AA}, \mathrm{CA}, \mathrm{AC}$ および $\mathrm{ACA}$ に対してそれぞれ， 72，68，71，69および76mm であった.

鋼板, CFRP 板およびAL 板の各接着面を, \#100 のサン ドペーパで研磨し, 油脂を拭き取ってからそれぞれ接着し た. 鋼板の片面に CFRP 板および $\mathrm{AL}$ 板を接着し室温 $20^{\circ} \mathrm{C}$ の恒温状態で 1 日養生した後，もう片面に同様にして 
表一1 計測した試験体の寸法と $\alpha_{v}$ の值および試験時の温度

\begin{tabular}{|c|c|c|c|c|c|c|c|}
\hline 試験体 & $\begin{array}{c}\text { 鋼板の幅 } \\
b_{s}[\mathrm{~mm}]\end{array}$ & $\begin{array}{c}\mathrm{CFRP} \text { 板の } \\
\text { 幅 } b_{f}[\mathrm{~mm}]\end{array}$ & $\begin{array}{c}\mathrm{AL} \text { 板の幅 } \\
b_{a}[\mathrm{~mm}]\end{array}$ & $\begin{array}{c}\alpha_{v} \\
{[\mu \rho \mathrm{C}]}\end{array}$ & $\begin{array}{c}\text { 接着剂の平 } \\
\text { 均厚さ }[\mathrm{mm}]\end{array}$ & $\begin{array}{c}\text { 温度上昇時 } \\
T_{1}, T_{2}\left[{ }^{\circ} \mathrm{C}\right]\end{array}$ & $\begin{array}{c}\text { 温度下降時 } \\
T_{1}, T_{2}\left[{ }^{\circ} \mathrm{C}\right]\end{array}$ \\
\hline $\mathrm{CC}$ & 25.2 & 23.1 & - & 0.8 & 0.16 & $20.0,38.5$ & $38.5,20.0$ \\
\hline $\mathrm{AA}$ & 25.6 & - & 25.1 & 21.4 & 0.13 & $20.0,38.5$ & $38.5,20.0$ \\
\hline $\mathrm{CA}$ & 25.4 & 25.3 & 25.1 & 11.0 & 0.14 & $20.0,38.5$ & $38.5,20.0$ \\
\hline $\mathrm{AC}$ & 25.5 & 24.0 & 23.7 & 11.1 & 0.14 & $20.0,38.5$ & $38.5,20.0$ \\
\hline $\mathrm{ACA}$ & 25.4 & 25.1 & 25.0 & 11.0 & 0.13 & $21.2,37.1$ & $37.1,20.9$ \\
\hline
\end{tabular}

表-2 材料定数

(a) 鋼材

\begin{tabular}{|c|c|c|}
\hline \multicolumn{2}{|l|}{ 鋼種 } & SS400 \\
\hline \multicolumn{2}{|l|}{ 板厚 $t_{s}$} & 4.2 \\
\hline \multicolumn{2}{|c|}{ 線膨脹係数 $\alpha_{s}[\mu \rho \mathrm{C}]$} & 11.3 \\
\hline \multicolumn{2}{|c|}{ ヤング率 $E_{s}[\mathrm{GPa}]$} & 205 \\
\hline \multirow{2}{*}{ 降伏応力 $\sigma_{Y}[\mathrm{MPa}]$} & 上降伏点 & 332 \\
\hline & 下降伏点 & 329 \\
\hline \multicolumn{2}{|c|}{ 引張強さ[MPa] } & 444 \\
\hline \multicolumn{2}{|c|}{ ポアソン比 } & 0.29 \\
\hline \multicolumn{2}{|c|}{ 伸び率[\%] } & 41.9 \\
\hline
\end{tabular}

(c) 接着鼡

\begin{tabular}{|c||c|}
\hline ガラス転移温度 $\mathrm{Tg}\left[{ }^{\circ} \mathrm{C}\right]$ & $74.0^{*}$ \\
\hline 可使時間[分] & $37^{*}$ \\
\hline 引張せん断強度[MPa] & $23.8^{*}$ \\
\hline 圧縮弾性係数[GP] & $2.61^{*}, 1.60$ \\
\hline ポアソン比 & 0.35 \\
\hline
\end{tabular}

$*:$ 材料試験成績書の值

$\mathrm{CFRP}$ 板と $\mathrm{AL}$ 板を接着し, 室温 $20^{\circ} \mathrm{C}$ の恒温状態で 1 週間 以上養生した.

計測した試験体の各寸法を表一 1 に示寸. 各材料の厚さ は表一2の材料定数に示している. 接着剤の厚さは，ノギ スで計測した試験体の全厚さから，鋼板および接着した $\mathrm{CFRP}$ 板と $\mathrm{AL}$ 板の厚さを引いて, 接着剤層の数で除した 平均厚さが示されている.

図一5に, 試験体に貼付けたひずタゲージの位置を示し ている. 鋼板の両側面と, 最外に接着された CFRP 板ある いは AL 板の両表面に普通鋼用(線澎張係数 $\left.11.7 \mu{ }^{\circ} \mathrm{C}\right)$ のひ ずみゲージを貼付けている.

\section{2 試験体に用いた材料の特性}

試験体に用いた鋼板，CFRP 板，AL 板およひ接着剤の 材料定数を表一2 に示寸. 鋼板, CFRP 板および AL 板は 引張試験および, 温度変化を与えた試験から得られた值を 示している. 接着剤の材料定数は, 材料試験成績書の值に 加え, 試験体で用いた接着剤で作成した立方体(一辺 $14 \mathrm{~mm})$ の供試体の土縮試験 $\left(20^{\circ} \mathrm{C}\right)$ から得られた圧縮弾性係 (b) CFRP 板

\begin{tabular}{|c||c|}
\hline 板厚 $t_{f}$ & 1.0 \\
\hline 線膨張係数 $\alpha_{f}[\mu \rho \mathrm{C}]$ & 0.8 \\
\hline ヤング率 $E_{f}[\mathrm{GPa}]$ & 141 \\
\hline 引張強さ $[\mathrm{MPa}]$ & 2801 \\
\hline
\end{tabular}

(d) アルミニウム合金板

\begin{tabular}{|c||c||c|}
\hline アルミニウム合金 & $\mathrm{A} 5052$ & $\mathrm{~A} 5052$ \\
\hline 板厚 $t_{a}$ & 1.0 & 2.0 \\
\hline 線膨張係数 $\alpha_{a}[\mu \rho \mathrm{C}]$ & 21.4 & 21.4 \\
\hline ヤング率 $E_{a}[\mathrm{GPa}]$ & 70.0 & 69.7 \\
\hline $0.2 \%$ 而力 $\sigma_{0.2}[\mathrm{MPa}]$ & 227 & 190 \\
\hline 引張強さ $[\mathrm{MPa}]$ & 283 & 252 \\
\hline ポアソン比 & 0.33 & 0.33 \\
\hline 伸び率 $[\%]$ & 8.3 & 10.7 \\
\hline \multicolumn{2}{|c}{} \\
\end{tabular}

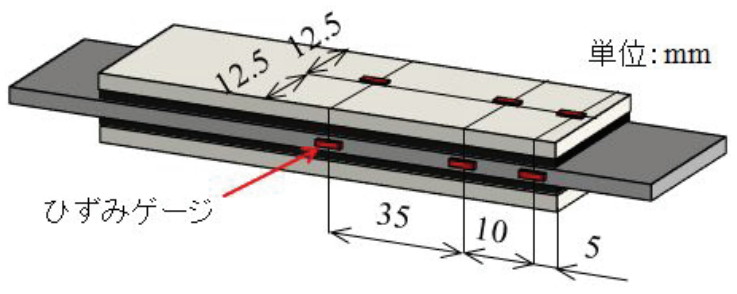

図-5 ひずみの計測位置

数とポアソン比も示している.

表一2 に示寸鋼板, CFRP 板および AL 板の線膨張係数 は，次節で説明する温度変化試験において，単体の鋼板， CFRP 板および AL 板に生じたひずみから次式を利用して 算出した.

$$
\alpha=\frac{\left\{\varepsilon_{m}\left(T_{2}\right)+11.7 T_{2}+\varepsilon_{g}\left(T_{2}\right)\right\}-\left\{\varepsilon_{m}\left(T_{1}\right)+11.7 T_{1}+\varepsilon_{g}\left(T_{1}\right)\right\}}{T_{2}-T_{1}}
$$

ここに

$$
\begin{aligned}
\varepsilon_{g}(T)= & -26+2.2 T-0.47 \times 10^{-1} T^{2} \\
& +0.12 \times 10^{-3} T^{3}+0.72 \times 10^{-6} T^{4}
\end{aligned}
$$


$\alpha \quad$ : 鋼板, CFRP板あるいはAL板の線膨張係数 $[\mu \rho \mathrm{C}]$,

$\varepsilon_{m}(T) \quad$ : 温度 $T\left[{ }^{\circ} \mathrm{C}\right]$ のときの鋼板，CFRP板あるい はAL板に接着したひずみゲージから計測 されたひずみ $[\mu]$,

$T_{1}, T_{2}$ : それぞれ, 試験開始時と終了時の温度 $\left[{ }^{\circ} \mathrm{C}\right]$. $\varepsilon_{g}(T)[\mu]$ ，自己温度補償ひずみゲージの見脚けひず みの近似式であり，製造ロットによって係数が異なる.

表一2 から，試験体に用いた鋼板，CFRP 板および AL 板の各ヤング率と各線膨長係数は，それぞれ設計で仮定し た各材料の值と同程度であることがわかる．表一1，2 の 計測寸法と材料定数を式(1) 一代入し算出された CFRP 板 と $\mathrm{AL}$ 板からなる合成板の線膨張係数 $\alpha_{v}$ を表一 1 に示寸. 試験体 CA, AC およびACA に対して, 合成板の線膨張係 数 $\alpha_{v}$ は, 鋼の線膨張係数 $\alpha_{s}$ に近い值になっていることが わかる.

\section{3 試験方法}

本研究では, 乾燥炉を用いて, 温度変化試験を行った。 $20^{\circ} \mathrm{Cl}$ 設定された恒温室に乾燥炉を設置し, 炉内に試験体 を鉛直に吊るし，扉を開けた状態で 2 時間程度放置した. その後，ひずみを計測し，乾燥炉の扉を閉め，炉内の設定

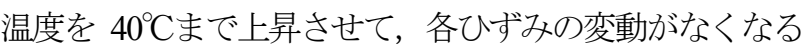
まで温度を保持した後, ひずみを計測して温度上昇に対す る試験とした. さらに, その状態から乾燥炉の扉を開けて,

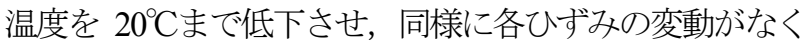
なった後, ひずみを計測して温度下降に対する試験とした. 各試験体に加え，単体の鋼板，CFRP 板および AL 板も同 様に温度変化を与えてひずみを計測した. 試験体の温度は 熱伝対を用いて計測した. 実際に計測された試験開始時と 終了時の温度 $T_{1}, T_{2}$ を表一 1 に示している.

\section{4. 試験結果}

計測された鋼板に生じるひずみ $\varepsilon_{s m}$ と単体の鋼板に生 じるひずみ $\varepsilon_{s n}$ および鋼のヤング率 $E_{s}$ を用いて, 次式か ら鋼板に生じる熱応力 $\sigma_{s}$ を算出した.

$$
\sigma_{s}=E_{s}\left(\varepsilon_{s m}-\varepsilon_{s n}\right)
$$

同様にして，試験体の CFRP 板あるいは AL 板に生じる ひずみおよび単体の CFRP板あるいは AL 板に生じるひず みを用いて, 最外のCFRP板あるいはAL板の熱忘力 $\sigma_{f}$, $\sigma_{a}$ を算出した. 温度上昇時および下降時の各試験体に生 じる熱応力を図一6〜10 にそれぞれ示す. 鋼板に生じる熱 応力は，鋼板の両側面の平均值を示し，CFRP 板および $\mathrm{AL}$ 板に生じる熱応力は, 上下面の平均值を示している. 困の横軸は, CFRP 板と $\mathrm{AL}$ 板の接着長さの中央からの距 離 $x$ (図一1〜4 参照)を示している. 図一6〜10 には, 後の 第 5 章で説明する数值解析の結果も実線と破線で示され ている.

図一6〜10からわかるように，温度上昇時と降下時に生
じる熱㐫力は，符号が異なるのみで絶対值はほぼ等しい.

図一6，7から，温度上昇時, CFRP 板のみが接着された

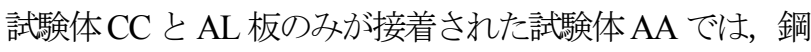
板に, 圧縮および引張の熱応力がそれぞれ生じていること がわかる. CFRP 板あるいは $\mathrm{AL}$ 板の端部では，鋼板に生 じる熱応力の值は小さく $x=0$ の位置で, 大きな引張あ るいは圧縮の熱応力が生じている. $x=0$ の位置の鋼板お よびCFRP 板に生じる熱応力は, 部材内力のつり合いから 導出される次式に，表一 1,2 の計測寸法と材料定数を代 入して算出された值 $\sigma_{s T}, \sigma_{f T}$ (図中の $x=0$ の位置の とほぼ一致している。

$$
\begin{gathered}
\sigma_{s T}=-\left(1-\xi_{0}\right) E_{s}\left(\alpha_{s}-\alpha_{f}\right)\left(T_{2}-T_{1}\right) \\
\sigma_{f T}=-\frac{A_{s}}{2 A_{f}} \sigma_{s T}
\end{gathered}
$$

ここに，

$$
\xi_{0}=\frac{E_{s} A_{s}}{E_{s} A_{s}+2 E_{f} A_{f}}
$$

式(6)（8)の CFRP 板の断面 $A_{f}$ と材料定数 $E_{f}, \alpha_{f}$ を それぞれ $\mathrm{AL}$ 板の $A_{a}, E_{a}$ および $\alpha_{f}$ に置換することによ り, 試験体 $\mathrm{AA}$ の鋼板と $\mathrm{AL}$ 板に生じる熱忘力の収束值 $\sigma_{s T}, \sigma_{a T}$ がそれぞれ計算できる.

図一8〜10 から, 試験体 $\mathrm{CA}, \mathrm{AC}$ およびACA では, $x=0$ の位置の鋼板に生じる熱応力がほぼ 0 になっていること がわかる．試験体 CA，AC では，補強板の端部近傍の鋼 板に若干熱応力が生じているが，試験体 ACA では，接着 端部近傍においても鋼板に生じる熱応力が低減されてい ることがわかる，したがって，式(2)で算出される CFRP 板の伸び岡性に対する AL 板の伸ひ風性の比を満足するよ うに，CFRP 板およびAL 板を接着することにより，鋼板 に生じる熱応力を大幅に低減できる.

一方, 図一8〜10 から, 試験体 $\mathrm{CA}, \mathrm{AC}$ およ゙ $\mathrm{ACA} の$ 最外の CFRP 板あるいは $\mathrm{AL}$ 板に生じる熱応力は, 試験体 $\mathrm{CC}\left(\right.$ 図一6)あるいは試験体 $\mathrm{AA}\left(\right.$ 図一7)に生じる熱応力 $\sigma_{f}$, $\sigma_{a}$ よりも大きくなっている. これは，鋼板と CFRP 板あ るいは鋼板と $\mathrm{AL}$ 板の線膨張係数の差より, CFRP 板と $\mathrm{AL}$ 板の線膨張係数の差が大きいためである.

試験体 CA，AC および ACA の $x=0$ の位置の鋼板, CFRP 板および AL 板に生じる熱灾力は，鋼板，CFRP 板 および AL 板の内力のつり合いから導出される次式に, 表 $-1,2$ の計測寸法と材料定数を代入して算出された值 $\sigma_{s T}$, $\sigma_{f T}$ および $\sigma_{a T}$ (図中の $x=0$ の位置の听とほぼ一致し ている.

$$
\begin{gathered}
\sigma_{s T}=-E_{s}\left\{(1-\xi)\left(\alpha_{s}-\alpha_{f}\right)+\frac{J}{1+J}\left(\alpha_{f}-\alpha_{a}\right)\right\}\left(T_{2}-T_{1}\right) \\
\sigma_{f T}=E_{f}\left\{\xi\left(\alpha_{s}-\alpha_{f}\right)-\frac{J}{1+J}\left(\alpha_{f}-\alpha_{a}\right)\right\}\left(T_{2}-T_{1}\right)
\end{gathered}
$$




$$
\sigma_{a T}=E_{a}\left\{\xi\left(\alpha_{s}-\alpha_{f}\right)+\frac{1}{1+J}\left(\alpha_{f}-\alpha_{a}\right)\right\}\left(T_{2}-T_{1}\right)
$$

ここに，

$$
\xi=\frac{E_{s} A_{s}}{E_{s} A_{s}+2\left(E_{f} A_{f}+E_{a} A_{a}\right)}
$$

$\sigma_{s}(x), \quad \sigma_{f}(x)[\mathrm{MPa}]$

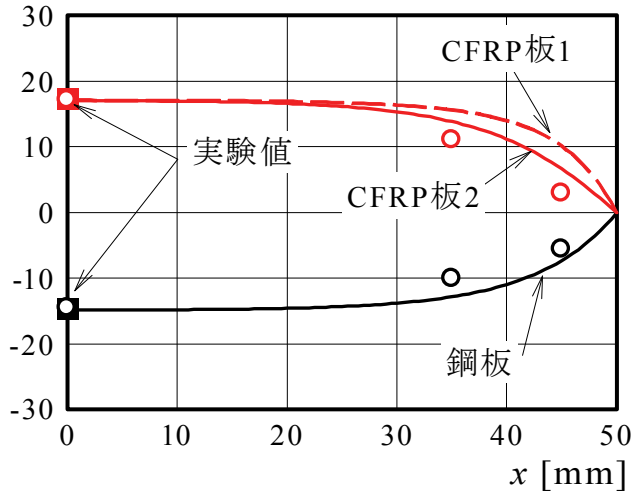

(a) 温度上昇

$$
J=\frac{2 E_{a} A_{a}}{E_{s} A_{s}+2 E_{f} A_{f}}
$$

試験体ACAに対して, AL板の断面積 $A_{a}$ は, 2枚のAL板 の断面積の和を与えた.

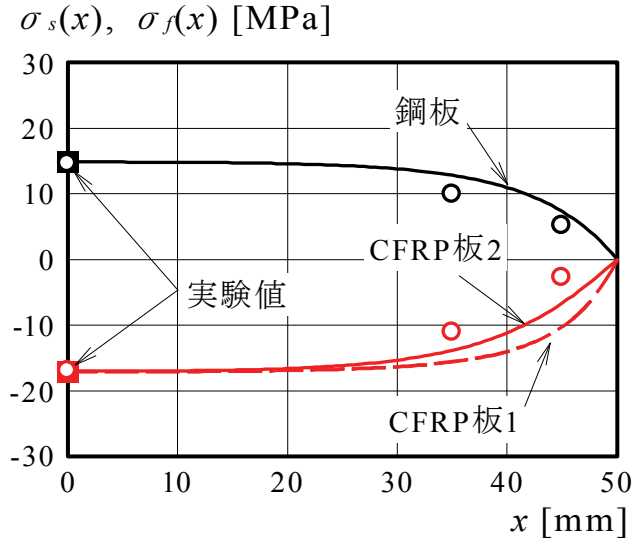

(b) 温度下降

図-6 試験体CC

$\sigma_{s}(x), \quad \sigma_{a}(x)[\mathrm{MPa}]$

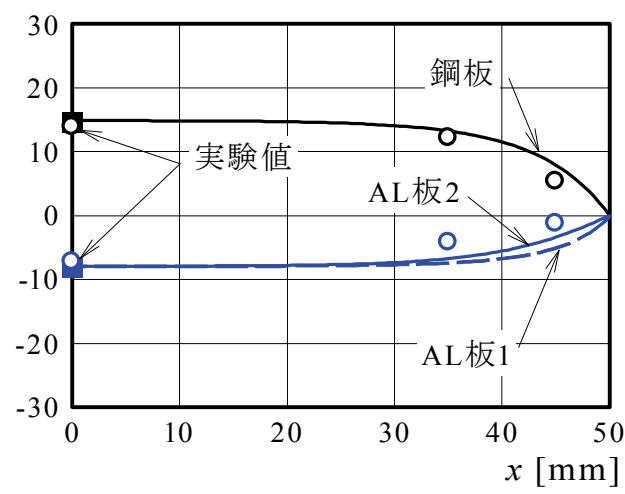

(a) 温度上昇

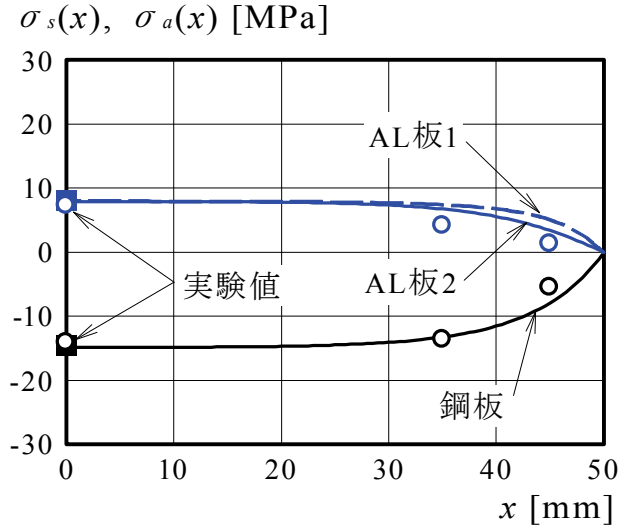

(b) 温度下降

図-7 試験体AA

$\sigma_{s}(x), \quad \sigma_{f}(x), \quad \sigma_{a}(x)[\mathrm{MPa}]$

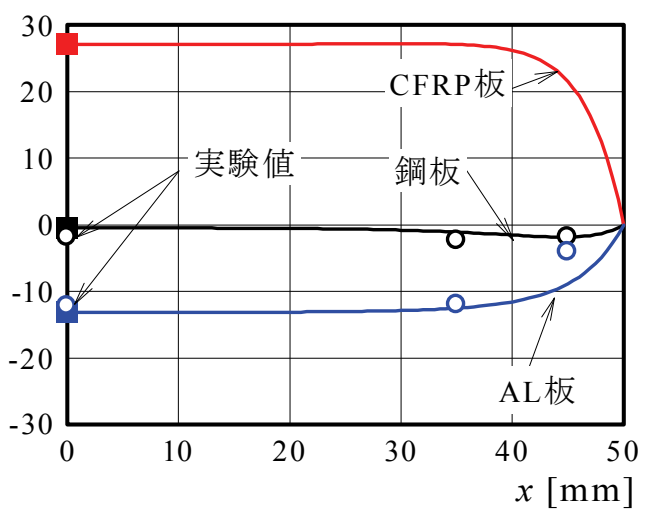

(a) 温度上昇

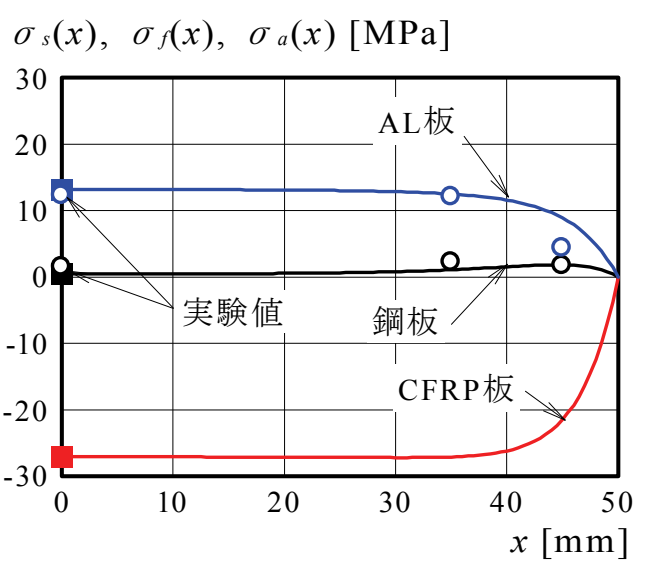

(b) 温度下降

図-8 試験体CA 
$\sigma_{s}(x), \quad \sigma_{f}(x), \quad \sigma_{a}(x)[\mathrm{MPa}]$

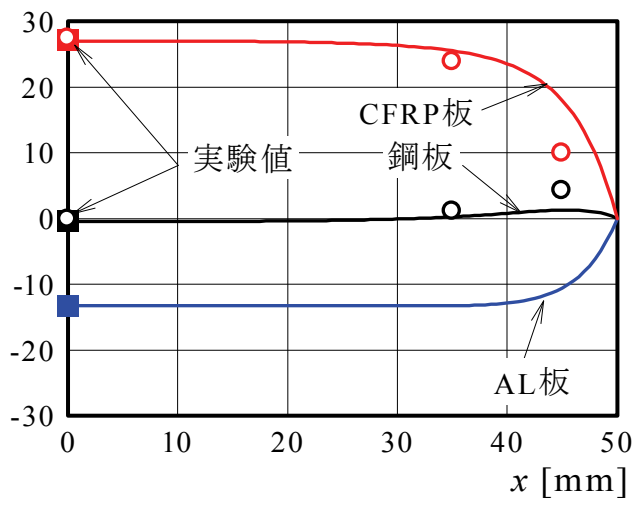

(a) 温度上昇

$\sigma_{s}(x), \quad \sigma_{f}(x), \quad \sigma_{a}(x)[\mathrm{MPa}]$

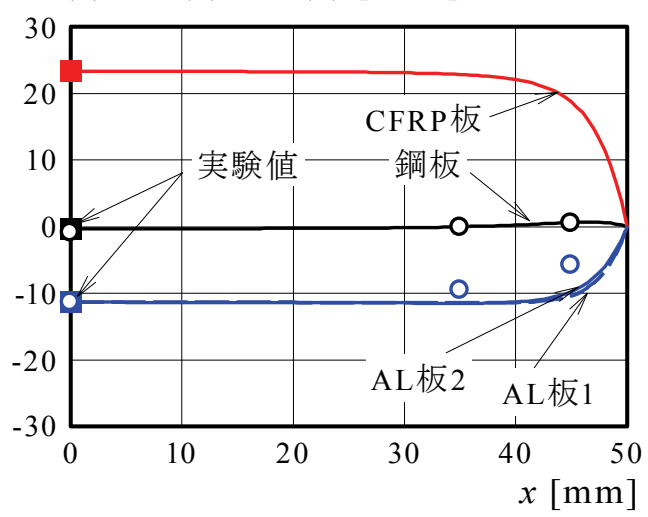

(a) 温度上昇 $\sigma_{s}(x), \quad \sigma_{f}(x), \quad \sigma_{a}(x)[\mathrm{MPa}]$

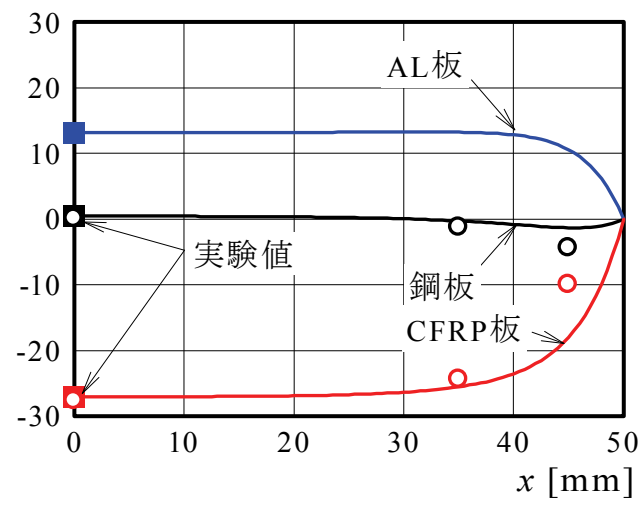

(b) 温度下降

図-9 試験体AC

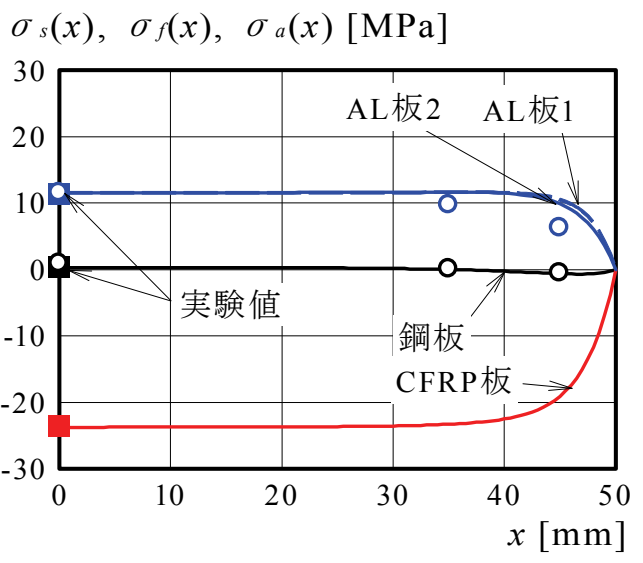

(b) 温度下降

図-10 試験体ACA

\section{5. 数值解析}

本章では，2枚あるいは3枚のCFRP板とAL板が鋼板の上 下面に接着された場合に対して，数值解析によって鋼板， CFRP板およびAL板に生じる熱応力を算出する. 図一11に 示すように，鋼板に近い側から，補強板1，2 と番号付をし て数值解析を行う.

\section{1 解析方法 ${ }^{10)}$}

鋼板に生じる応力 $\sigma_{s}(x)$ とひずみ $\varepsilon_{s}(x)$ の関係および 補強板 $i$ に生じる応力 $\sigma_{i}(x)$ とひずみ $\varepsilon_{i}(x)$ の関係をそれ ぞれ次式で与える.

$$
\begin{aligned}
& \varepsilon_{s}(x)=\frac{d u_{s}(x)}{d x}=\frac{\sigma_{s}(x)}{E_{s}}+\varepsilon_{T s} \\
& \varepsilon_{i}(x)=\frac{d u_{i}(x)}{d x}=\frac{\sigma_{i}(x)}{E_{i}}+\varepsilon_{T i}
\end{aligned}
$$

$$
\begin{gathered}
\varepsilon_{T s}=\alpha_{s} \Delta T \\
\varepsilon_{T i}=\alpha_{i} \Delta T
\end{gathered}
$$

$E_{i} \quad$ : 補強板 $i$ のヤング率,

$\alpha_{i} \quad:$ 補強板 $i$ の線膨張係数,

$i \quad: 1$ から $N$ (積層数)までの整数.

接着剤 $i$ に生じるせん断忘力 $\tau_{i}(x)$ とせん断ひずみ $\gamma_{i}(x)$ の関係を次式で与える.

$$
\tau_{i}(x)=G_{e i} \gamma_{i}(x)=G_{e i} \frac{u_{i-1}(x)-u_{i}(x)}{h_{i}}
$$

ここに,

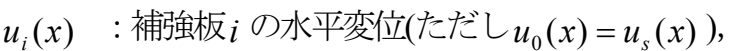

$G_{e i} \quad$ : 接着剤 $i$ のせん断弾性係数,

$h_{i} \quad$ : 接着剤 $i$ の厚さ.

式(14), (15)および(18)を行列・ベクトル形式で表すと次 式になる.

$$
\boldsymbol{\sigma}(x)=\mathbf{D}\left(\boldsymbol{\varepsilon}(x)-\boldsymbol{\varepsilon}_{T}\right)
$$

ここに, 


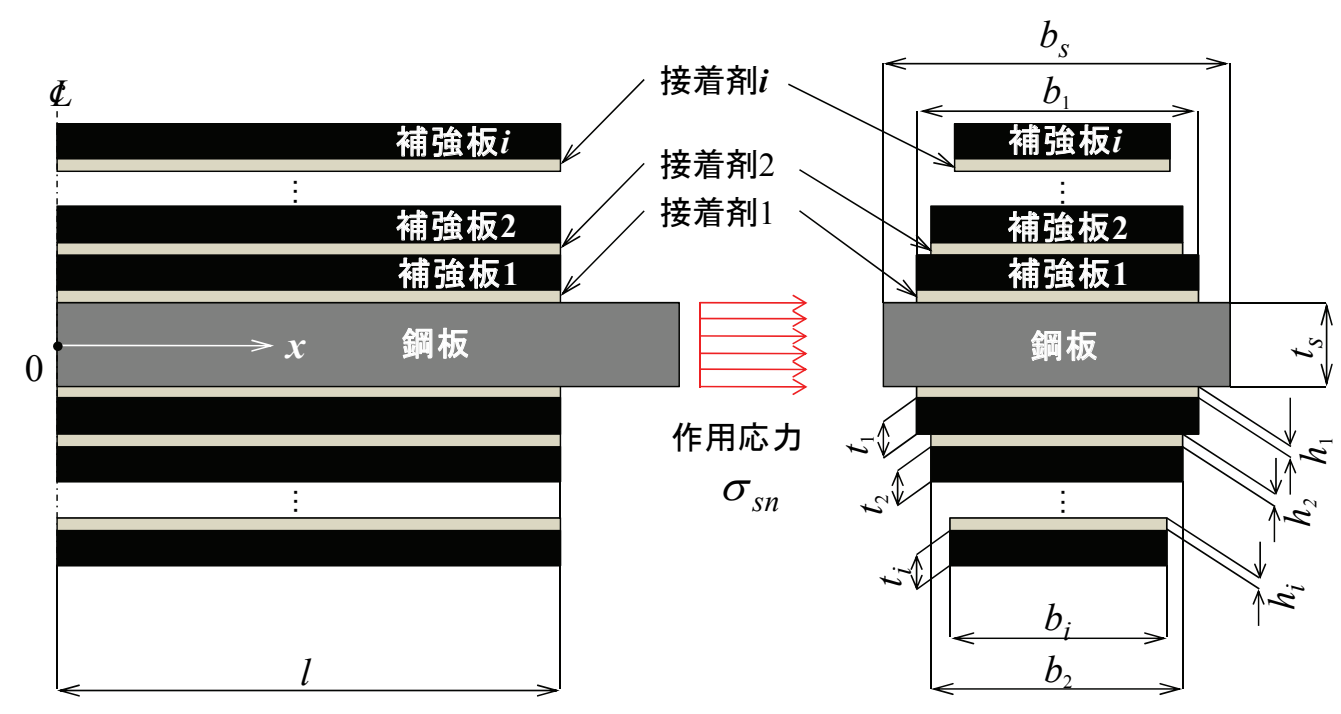

(a) 縦断面図

(b) 横断面図

図ー11 複数の補強板が接着された鋼板の側面と断面

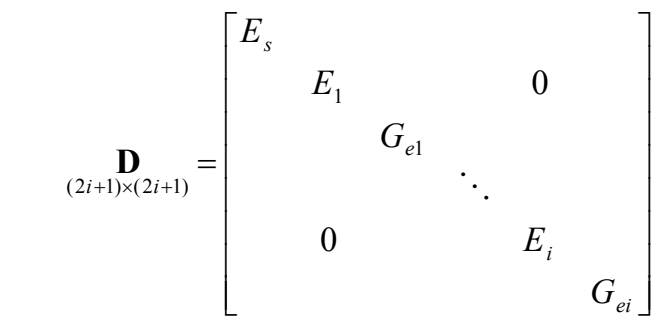

$\underset{(2 i+1) \times 1}{\boldsymbol{\sigma}(x)}=\left\{\begin{array}{llllll}\sigma_{s}(x) & \sigma_{1}(x) & \tau_{1}(x) & \cdots & \sigma_{i}(x) & \tau_{i}(x)\end{array}\right\}^{T}$

$$
\underset{(2 i+1) \times 1}{\boldsymbol{\varepsilon}(x)}=\left\{\begin{array}{llllll}
\varepsilon_{s}(x) & \varepsilon_{1}(x) & \gamma_{1}(x) & \cdots & \varepsilon_{i}(x) & \gamma_{i}(x)
\end{array}\right\}^{T}
$$

$$
\underset{(2 i+1) \times 1}{\boldsymbol{\varepsilon}_{T}}=\left\{\begin{array}{llllll}
\varepsilon_{T s} & \varepsilon_{T 1} & 0 & \cdots & \varepsilon_{T i} & 0
\end{array}\right\}^{T}
$$

図一12に示寸, 複数の補強板が接着された鋼板の微小区 間の水平方向の力のつり合いから, 導出されるひずみの関 係式の行列・ベクトル形式が次式で与えられる ${ }^{11)}$.

$$
\frac{d \boldsymbol{\varepsilon}(x)}{d x}=A \boldsymbol{\varepsilon}(x)
$$

ここに,

$$
\underset{3 \times 3}{\mathbf{A}}=\left[\begin{array}{ccc}
0 & 0 & \frac{2 G_{e 1}}{E_{s} t_{s}} \cdot \frac{b_{1}}{b_{s}} \\
0 & 0 & -\frac{G_{e 1}}{E_{1} t_{1}} \\
\frac{1}{h_{1}} & -\frac{1}{h_{1}} & 0
\end{array}\right](N=1)
$$

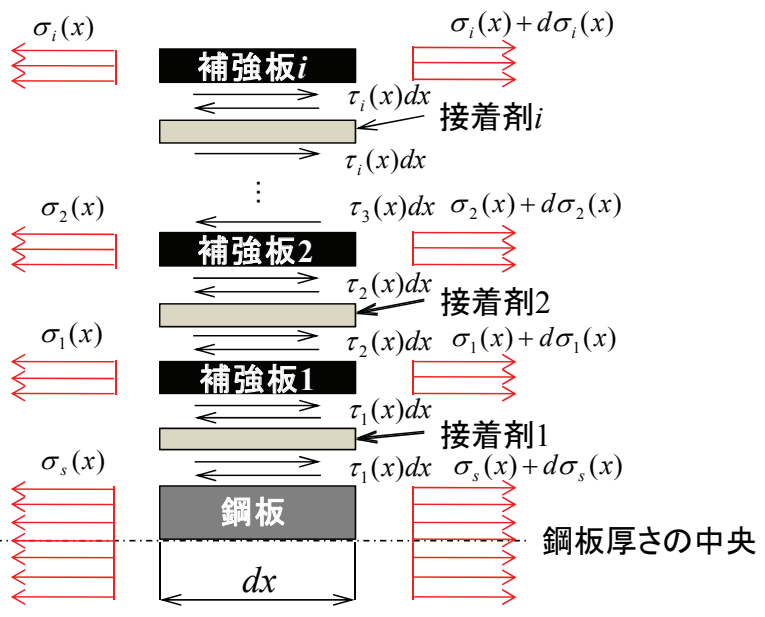

図ー12 複数の補強板が接着された鋼板の微小区間の 水平方向の力のつり合い

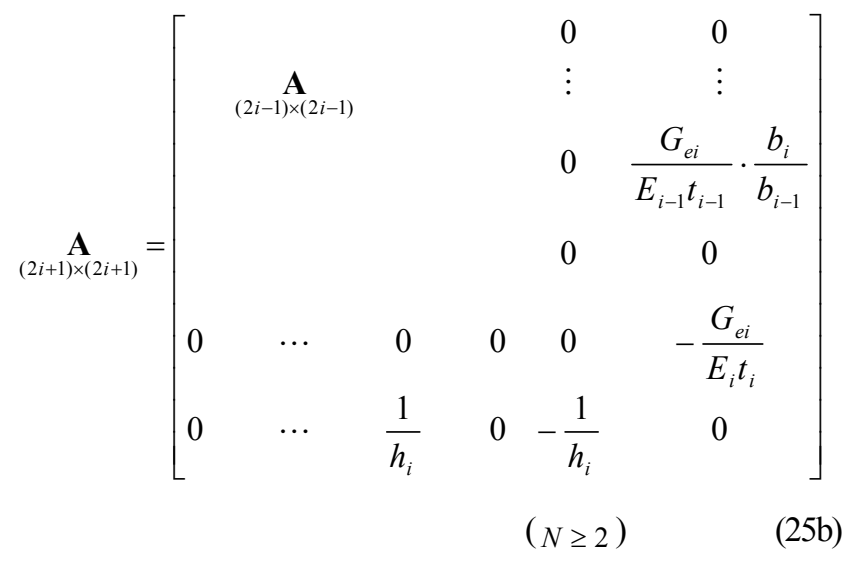

ここに，

$t_{s}, t_{i}$ : それぞれ鋼板および補強板 $i$ の厚さ,

$b_{s}, b_{i}$ : それぞれ鋼板および補強板 $i$ の幅 $\left(b_{i} \leq b_{i-1} \leq b_{s}\right)$.

式(24)の一般解は，次式で与えられる ${ }^{11) ~ 13)}$. 


$$
\boldsymbol{\varepsilon}(x)=\mathbf{Y}(x) \mathbf{C}
$$

ここに

$$
\begin{gathered}
\underset{(2 i+1) \times 1}{\mathbf{C}}=\left\{\begin{array}{lll}
C_{1} & \cdots & C_{j}
\end{array}\right\}^{T} \\
\underset{(2 i+1) \times(2 i+1)}{\mathbf{Y}(x)}=\mathbf{T e}^{\Lambda(x)} \mathbf{T}^{-1} \\
\underset{(2 i+1) \times(2 i+1)}{\mathbf{e}^{\Lambda(x)}}=\left[\begin{array}{lll}
e^{\lambda_{1} x} & & 0 \\
& \ddots & \\
0 & & e^{\lambda_{j} x}
\end{array}\right] \\
\underset{(2 i+1) \times(2 i+1)}{\mathbf{T}}=\left[\begin{array}{lll}
\mathbf{v}_{1} & \cdots & \mathbf{v}_{j}
\end{array}\right]
\end{gathered}
$$

$\lambda_{j}:$ 行列 $\mathbf{A}$ の $j$ 番目の固有值,

$\mathbf{v}_{j}: j$ 番目の固有值に対する固有ベクトル,

$j \quad: 1$ から $2 i+1$ までの整数.

未定係数べクトル $\mathbf{C}$ は, 境界条件を与えて決定される. 図一11に示寸複数の補強板が接着された鋼板に対して, 補 強板の端部において, 鋼板に生じる応力 $\sigma_{s}(x)$ が作用応力 $\sigma_{s n}$ と等しく, 各補強板に生じる応力 $\sigma_{i}(x)$ が全て 0 になり, さらに補強板の付着中央 $(x=0)$ で各接着剤に生じるせん 断灾力 $\tau_{i}(x)$ が全て 0 になる境界条件を与えて, 未定係数べ クトル $\mathbf{C}$ が次式で算出される.

$$
\mathbf{C}=\mathbf{B}^{-1}\left(\mathbf{D}^{-1} \boldsymbol{\sigma}_{0}+\boldsymbol{\varepsilon}_{T}\right)
$$

ここに,

$$
\underset{(2 i+1) \times 1}{\boldsymbol{\sigma}_{0}}=\left\{\begin{array}{llll}
\sigma_{s n} & 0 & \cdots & 0
\end{array}\right\}^{T}
$$

$\underset{\mathbf{B}}{\mathbf{B}(2 i+1)}: 1$ 行目および $2 i$ 行目は，それぞれ $\mathbf{Y}(l)$ の1 行目および $2 i$ 行目の值, $2 i+1$ 行目は $\mathbf{Y}(0)$ の $2 i+1$ 行目の值を有寸る行列,

$\sigma_{s n}$ : 作用応力.

したがって, 複数の補強板が接着された場合に対して, 式(31)から算出される未定係数ベクトルを式(26)に代入し， 式(19)から, 鋼板, 各補強板および各接着剂に生じる応力 が数值解析によって計算できる.

\section{2 数值解析結果}

\section{(1) 鋼板, CFRP板およびAL板に生じる応力}

表一 1,2 の試験体の寸法と材料定数を与えて, 算出し た数值解析結果を図一6〜10 に実線と破線で示している. 解析值には, CFRP 板を形成する樹脂の影響, 寸なわち CFRP 板内の樹脂によるせん断遅れが考慮されていない. したがって, 接着端部近傍で, 解析值が実験值よりも若干 大きくなっているが, 両者は同様な傾向を示していること がわかる。

図-8〜10 に示寸ように, 解析によって, 試験体 CA, AC および ACA の接着端部の鋼板に若干生じる熱㐫力も 評価できていることがわかる. 温度上昇時, 試験体 CA で は，接着端部の鋼板の熱怘力は圧縮であるが，試験体 $\mathrm{AC}$
では引張が生じている.この理由は, 鋼板から, 補強板 1 に軸力が伝達され, 次に補強板 1 から補強板 2 に軸力が伝 達されるため, 接着端部近傍の鋼板は，他の補強板と比心゙ て補強板 1 の線膨張係数の影響を強く受けるためである. さらに, 解析結果では, 積層数が 3 層の試験体 ACA の接 着端部の鋼板に生じる熱忘力が試験体 $\mathrm{CA}$ および $\mathrm{AC}$ より も小さくなっており, 実験結果と同じ傾向を示した.

CFRP 板あるいは $\mathrm{AL}$ 板に生じる応力は, $x=0$ の位置 では, 解析值と実験值がほぼ一致しているが, 試験体 CA, $\mathrm{AC}$ およびACA では, 接着端部近傍 $(x=45 \mathrm{~mm})$ において, 両者の值に差が見られた。 これは, 本解析が軸力のみを取 り扱った手法であるため，CFRP 板あるいは AL 板の上下 面に生じるせん断応力の差に起因する曲げモーメントに よる表面応力が考慮されていないことが原因であると考 えられる. CFRP 板あるいは AL 板の接着端部近傍に生じ る曲げモーメントによって接着剤に垂直応力が生じるの で，CFRP 板や AL 板のはく離を評価する際には，それら に生じる曲げモーメントを明らかにする必要があると考 えられる。

\section{(2) 接着剤に生じるせん断応力}

数值解析で得られた, 温度上昇時に対寸る各試験体の接 着剂に生じるせん断応力の分布を図一13〜17に示す.これ らの図からわかるように，試験体CCおよびAAでは，各接 着剂に生じるせん断応力の符号は等しく, 鋼板に近い 接着 剂1に生じるせん断応力の絶対值が接着剂2のそれよりも 大きくなる，一方，試験体CAおよびACでは，接着剂1と2 に生じるせん断応力の符号が異なり，接着剤2に生じるせ ん断応力の絶対值が接着剤1のそれよりも大きい. さらに, 試験体CAおよびACの接着阂2に生じるせん断応力の絶対 值は，試験体CC，AAの接着剂1に生じるせん断応力の絶 対值よりも大きくなっている，試験体ACAでは，接着剂1 と3に生じるせん断応力の符号が等しく, 接着剤3に生じる せん断応力の絶対值が最大になる. さらに, 試験体ACA の接着剤3に生じるせん断応力の絶対值は, 試験体CC, AA の接着剤1に生じるせん断応力の絶対值よりも小さくなっ ている. これらの現象は, 鋼板とCFRP板, 鋼板とAL板お よびCFRP板とAL板の線膨張係数の差と各材料の伸び岡 性に依存している.

先に述べたように，実験で計測された最外のCFRP板あ るいはAL板の接着端部近傍の表面のひずタは，曲げモー メントによって生じるひずみを含んでいるので, それらの 值を用いて接着剤に生じるせん断応力が算出できない. 一 方, 鋼板では, 上下面に同方向にせん断応力が生じるため, 曲げモーメントが生じない.したがって, 鋼板応力の計測 值を利用して，接着剤1に生じるせん断応力を計算する.

接着剂1に生じるせん断応力と鋼板応力の間には, 以下 の関係がある ${ }^{14)}$.

$$
\tau_{1}(x)=\frac{t_{s}}{2} \cdot \frac{d \sigma_{s}(x)}{d x}
$$

ここに,

$\tau_{1}(x) \quad$ : 鋼板側から 1 層目の接着剂に生じるせん 断応力. 
$\tau(x)[\mathrm{MPa}]$

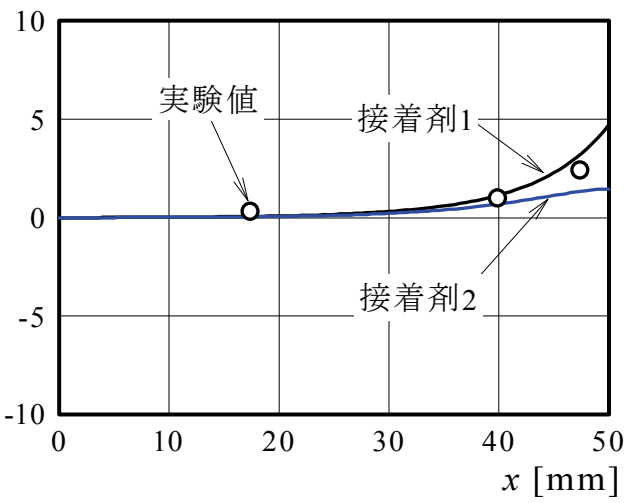

図-13 試験体CCの接着剤に生じるせん断応力

$\tau(x)[\mathrm{MPa}]$

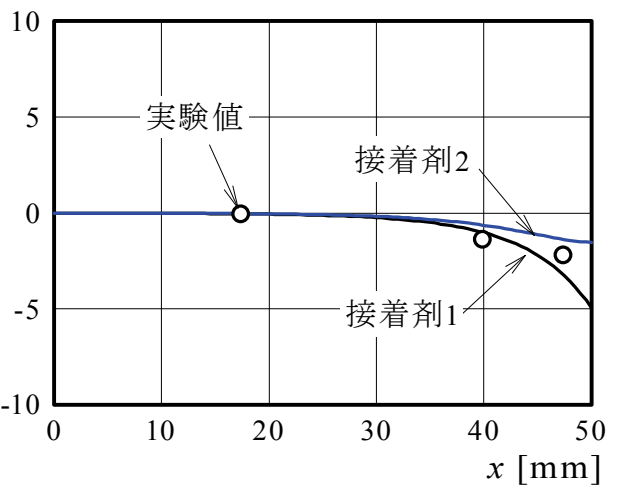

図-14 試験体AAの接着剂に生じるせん断応力

この式を差分の形で表すと次式になる.

$$
\tau_{1}\left(\frac{L_{2}+L_{1}}{2}\right)=\frac{t_{s}}{2} \cdot \frac{\sigma_{s}\left(L_{2}\right)-\sigma_{s}\left(L_{1}\right)}{L_{2}-L_{1}}
$$

ここに,

$L_{1} ， L_{2}$ : それぞれ，補強板の接着中央から鋼板応力 の計測位置までの距離 $\left(L_{1} \neq L_{2}\right)$.

各試験体の鋼板の熱応力を利用して式(34)から算出され る温度上昇時の接着剤 1 に生じるせん断応力 $\tau_{1}$ を図 -13 〜17にプロットしている. 鋼板に生じるひずみの計測点数 が少なく，それらの間隔が大きいため，精度の良い值は得 られていないが，これらの図から，実験值から算出した接 着剤 1 に生じるせん断応力は，解析值と同様な傾向を示し ていることがわかる，さらに，3層積層された試験体ACA の接着剤1に生じるせん断応力が最も低減されていること が実験值からも明らかである。

6. まとめ

本研究では，CFRP 板が上下面に刘称に接着された鋼板 を対象に, 温度変化によって鋼板に生じる熱応力を低減さ せる方法として, 線膨張係数が鋼の約 2 倍のアルミニウム 合金板を CFRP 板と共に鋼板に接着する方法を提案した. そして, 鋼板にCFRP 板とアルミニウム合金板を接着した
$\tau(x)[\mathrm{MPa}]$

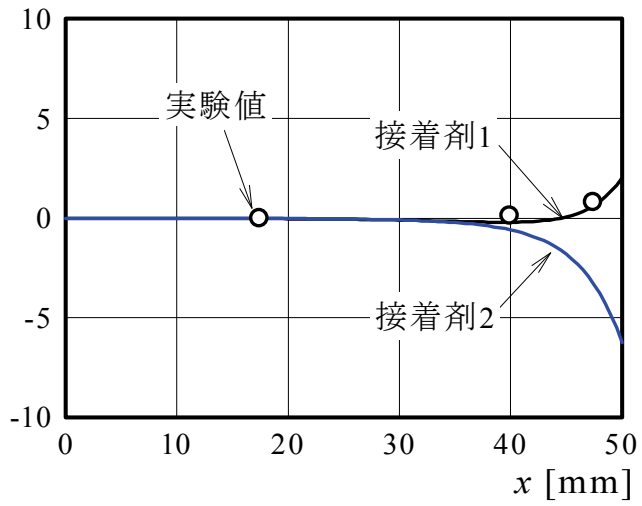

図－15 試験体CAの接着剤に生じるせん断応力

$\tau(x)[\mathrm{MPa}]$

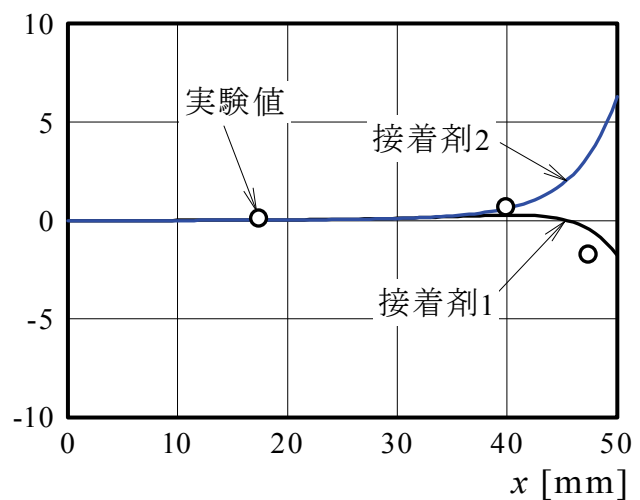

図-16 試験体ACの接着剤に生じるせん断応力

$\tau(x)[\mathrm{MPa}]$

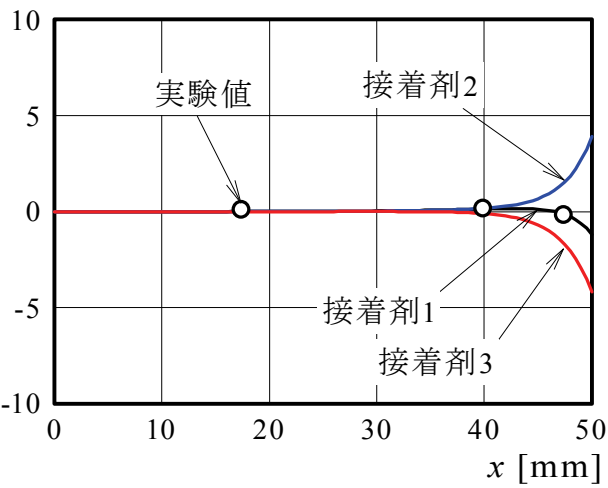

図-17＼cjkstart試験体ACAの接着剤に生じるせん断応力

試験体の温度変化試験および数值解析を行い, 開発した工 法による鋼板の熱応力の低減効果を明らかにした. 主な結 論を以下に示す.

1) アルミニウム合金板を CFRP 板と共に接着して, 鋼板 に熱応力が発生しないCFRP 板を用いた補修・補強工 法を開発した. CFRP 板の接着の中央で，鋼板に生じ る熱応力を 0 にするのに必要なアルミニウム合金板 の伸ひ岡性は式(2)から計算できる.

2) 式(2)を満足するように設計した CFRP 板とアルミニ ウム合金板が接着された鋼板の温度変化試験を行い, 接着端部の鋼板に若干熱応力が生じるが，CFRP 板と 
アルミニウム合金板の接着の中央では鋼板の熱志力 がほぼ 0 になることを示した.さらに補強板全体の伸 ひ岡性が等しい条件において, 補強板の積層数を増や すことによって接着端部の鋼板に生じる熱応力を小 さくできる. 接着端部に生じる鋼板の熱忍力の符号は, 鋼板に近い側の補強板の線膨張係数に依存する.

3) 開発した工法によって, 鋼板直上の接着剤に生じるせ ん断応力の絶対值が，CFRP板のみが接着されている 場合よりも小さくなることを示した. さらに，補強板 全体の伸ひ岡性が等しい条件において, 補強板の積層 数を増加させることによって鋼板直上の接着剤に生 じるせん断応力の絶対值を小さくできる.

\section{謝辞}

本研究の試験では, 京都大学工学部 4 回生の古谷貴洋君 にご協力頂いた。 ここに記して謝意を示します.

\section{参考文献}

1) Miller, T. C., Chajes, M. J., Mertz, D. R. and Hastings, J. N. : Strengthening of a steel bridge girder using CFRP plates, Journal of Bridge Engineering, ASCE, USA, Vol.6, pp.514-522, 2001.

2) 板垣一也, 渡邊憲市，鈴木博之：炭素繊維強化樹脂板 （カーボン板）による鋼橋補強の事例，第 8 回鋼構造 の補修・補強技術報告論文集，pp.49-54，2002.

3) 玉井宏章，高松隆夫，服部明生，灰谷徳治，櫻庭誠： 炭素繊維プレートによる化学プラント架構小ばり補岡 の施工例, 鋼構造年次論文報告集, 第 13 巻, pp.545-552, 2005.

4) Moy, S. S. J. and Bloodworth, A. G.: Strengthening a steel bridge with CFRP composites, Structures \& Buildings, Vol.160, Issue SB2, pp.81-93, 2007.

5) 石川敏之, 大倉一郎, 横田季彦, 斉藤 誠 : 温度変化 によって CFRP 板接着鋼板に生じるはく離せん断応力,
応用力学論文集，Vol.10，pp.963-970， 2007.

6) 山谷佑介, 姜 威, 中村一史, 前田研一, 鈴木博之, 入部孝夫，伊原啓裕 : 温度変化時における鋼板と CFRP 板の接着特性に関する実験的検討，土木学会第 63 回年 次学術講演会概要集 I, I-466, pp.931,932， 2008.

7) Schnerch, D., Dawood, M., Rizkalla, S. and Sumner, E. : Proposed design guidelines for strengthening of steel bridges with FRP materials, Construction and Building Materials, Vol.21, Issue 5, pp.1001-1010, 2007.

8) National Research Council - Advisory Committee on Technical Recommendations for Construction: Guidelines for the Design and Construction of Externally Bonded FRP Systems for Strengthening Existing Structures, CNR-DT 202/2005, 2007.

9) 大倉一郎, 長井和樹 : 鋼板に接着された複数枚の CFRP 板の必要接着長さとはく離せん断㐫力，土木学会論文 集A1，Vol.67, No.1，pp.72-85， 2011.

10)石川敏之，服部篤史，河野広隆 : アルミニウム合金板 接着による CFRP 板接着鋼板に生じる熱応力の低減, 土木学会論文集 A1，2011. (印刷中)

11)宮下 剛, 長井正嗣: 一軸引張りを受ける多層の CFRP が積層された鋼板の応力解析，土木学会論文集 $\mathrm{A}$, Vol.66, No.2, pp.378-392, 2010.

12)稲見武夫 : 理工系の基礎数学 3 - 常微分方程式，岩波書 店，1998.

13)神保秀一 : 数学基礎コース $=\mathrm{H} 4$ ・微分方程式概論, サイ エンス社, 1999.

14)大倉一郎，福井唯夫，中村圭吾，松上泰三 : 炭素繊維 シートによる鋼板応力の低下とはく離せん断応力, 土 木学会論文集，No.689/I-57，pp.239-249， 2001.

(2011 年3月 8 日 受付) 